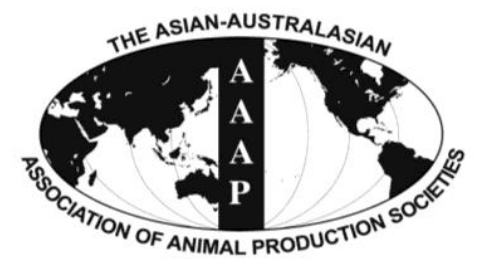

Asian-Aust. J. Anim. Sci.

Vol. 25, No. 4 : 502 - 514

April 2012

www.ajas.info

http://dx.doi.org/10.5713/ajas.2011.11300

\title{
A Physiological Stimulating Factor of Water Intake during and after Dry Forage Feeding in Large-type Goats
}

\author{
Tran Van Thang, Katsunori Sunagawa*, Itsuki Nagamine, Tetsuya Kishi and Go Ogura \\ Faculty of Agriculture, University of the Ryukyus, 1 Senbaru, Nishihara-cho, Okinawa 903-0213, Japan
}

\begin{abstract}
When ruminants consume dry forage, they also drink large volumes of water. The objective of this study was to clarify which factor produced when feed boluses enter the rumen is mainly responsible for the marked increase in water intake in the second hour of the $2 \mathrm{~h}$ feeding period in large-type goats fed on dry forage for $2 \mathrm{~h}$ twice daily. Six large-type male esophageal- and ruminalfistulated goats (crossbred Japanese Saanen/Nubian, aged 2 to 6 years, weighing $85.1 \pm 4.89 \mathrm{~kg}$ ) were used in two experiments. In experiment 1 , the water deprivation (WD) control and the water availability (WA) treatment were conducted to compare changes in water intake during and after dry forage feeding. In experiment 2, a normal feeding conditions (NFC) control and a feed bolus removal (FBR) treatment were carried out to investigate whether decrease in circulating plasma volume or increase in plasma osmolality is mainly responsible for the marked increase in water intake in the second hour of the $2 \mathrm{~h}$ feeding period. The results of experiment 1 showed that in the WA treatment, small amounts of water were consumed during the first hour of feeding while the majority of water intake was observed during the second hour of the $2 \mathrm{~h}$ feeding period. Therefore, the amounts of water consumed in the second hour of the $2 \mathrm{~h}$ feeding period accounted for $82.8 \%$ of the total water intake. The results of experiment 2 indicated that in comparison with the NFC control, decrease in plasma volume in the FBR treatment, which was indicated by increase in hematocrit and plasma total protein concentrations, was higher $(\mathrm{p}<0.05)$ in the second hour of the $2 \mathrm{~h}$ feeding period. However, plasma osmolality in the FBR treatment was lower $(\mathrm{p}<0.05)$ than compared to the NFC control from $30 \mathrm{~min}$ after the start of feeding. Therefore, thirst level in the FBR treatment was $82.7 \%$ less $(\mathrm{p}<0.01)$ compared with that in the NFC control upon conclusion of the 30 min drinking period. The results of the study indicate that the increased plasma osmolality in the second hour of the $2 \mathrm{~h}$ feeding period is the main physiological stimulating factor of water intake during and after dry forage feeding in large-type goats. (Key Words : Plasma Volume, Plasma Osmolality, Water Intake, Dry Forage Feeding, Large-type Goats)
\end{abstract}

\section{INTRODUCTION}

Okinawa is located in a sub-tropical zone with grass productivity levels higher than those in temperate area. However, because the land area available for use as grasslands in Okinawa is very limited, farmers are faced with the problem of securing sufficient feed for their animals. The advantages of drying fresh grass are the ability to store it for long periods of time, and to transport it to far off markets. Furthermore, dry forage can be stored in large amounts making large-scale livestock management possible in the rearing of ruminants. Ruminants that were fed on dry forage twice daily secrete large amounts of saliva during the initial stages of feeding. The main components of saliva are water and sodium bicarbonate which are made by

\footnotetext{
* Corresponding Author: K. Sunagawa. Tel : +81-98-895-8798, Fax : +81-98-895-8734, E-mail : b986094@agr.u-ryukyu.ac.jp Submitted Aug. 26, 2011; Accepted Dec. 5, 2011; Revised Dec. 13, 2011
}

components in the blood. During the initial stages of dry forage feeding, blood $\mathrm{pH}$ decreases and circulating plasma volume is reduced (Sasaki et al., 1975). On the other hand, in large-type goats were fed dry forage for $2 \mathrm{~h}$ twice daily, after 40 min of the feeding period had elapsed, ruminal absorption of salts from the consumed feed causes an increase in plasma osmolality and both dry forage intake and salivary secretion significantly decrease while water intake increases (Sunagawa et al., 2005; 2008). However, the mechanism involved in the increased water consumption during and after dry forage feeding is not clear.

Until now, the research on the mechanisms controlling feed and water intake has been conducted separately and therefore there are very few reports available on the interaction between the two behaviors. For farmers raising ruminants on a dry forage twice daily feeding system, large amounts of uneaten feed were observed whenever watering equipment was broken. Prasetiyono et al. (2000) reported 
that in goats fed dry forage twice daily, there is a negative correlation between the length of water deprivation time and dry forage intake. On the other hand, there are also reports of high positive correlation between dry forage intake and water intake (Paquay et al., 1970). From these reports, it is thought that the significant increase in water intake observed in the second hour of the $2 \mathrm{~h}$ feeding period in large-type goats fed dry forage for $2 \mathrm{~h}$ twice daily may be regulated by factors produced when feed boluses enter the rumen.

The objective of this study was to clarify which factor produced when feed boluses enter the rumen is mainly responsible for the marked increase in water intake in the second hour of the $2 \mathrm{~h}$ feeding period in large-type goats fed dry forage for $2 \mathrm{~h}$ twice daily. In order to achieve the objective of this study, animals were prepared with an esophageal fistula that was maintained over a long period of time.

\section{MATERIALS AND METHODS}

\section{Animals}

Six large-type male esophageal- and ruminal-fistulated goats (crossbred Japanese Saanen/Nubian, aged 2 to 6 years, weighing $85.1 \pm 4.89 \mathrm{~kg}$ ) were used in this study. The goats were maintained in individual metabolism cages (length 2

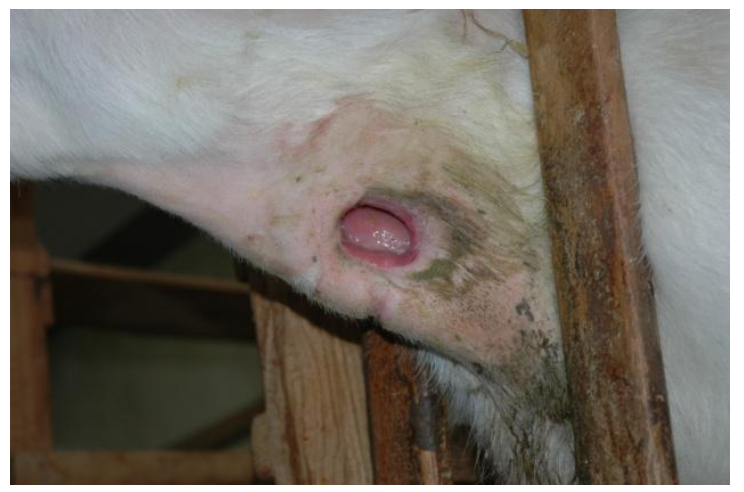

(A)

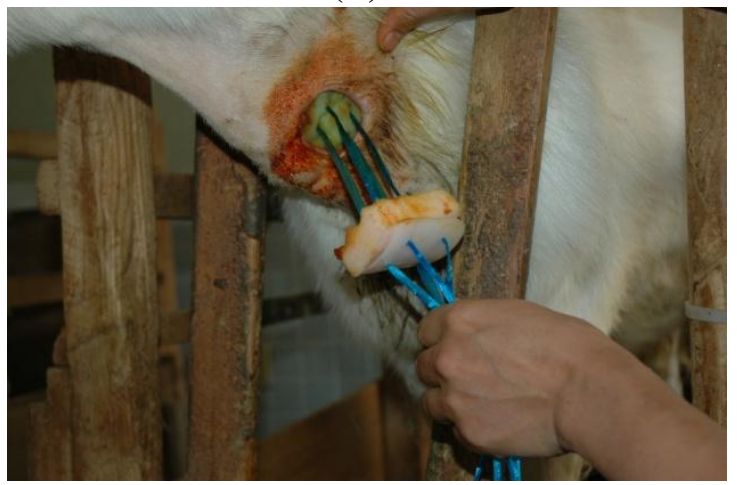

(C) $\mathrm{m} \times$ width $1 \mathrm{~m} \times$ height $2 \mathrm{~m}$ ) that allowed for the separate collection of urine and feces. The laboratory room was maintained under thermoneutral conditions (room temperature $21.4 \pm 0.37^{\circ} \mathrm{C}$; relative humidity $80.4 \pm 1.15 \%$ ).

On non-experimental days, the animals were fed twice daily at 10:00 $\mathrm{h}$ and 16:00 $\mathrm{h}$ for $2 \mathrm{~h}$ each time. During the morning feeding period (10:00 to $12: 00 \mathrm{~h}$ ), the animals were fed 1.5 to $2.5 \mathrm{~kg}$ of roughly crushed alfalfa hay cubes. At 16:00 h each day, the animals were fed $300 \mathrm{~g}$ of hay and $200 \mathrm{~g}$ of concentrated beef cattle feed and half a spoon of multivitamins. The animals were given $5 \mathrm{~L}$ of water at each meal.

\section{Esophageal fistulation in large-type goats}

Surgical technique: The esophageal fistulation was performed using a two-step operation for esophageal fistulation in sheep described by Kato et al. (1983). In the first step, the esophagus was adhered to the skin of the neck. In the second step that was carried out approximately two months after the first step operation, a fistula was established on the adhered esophagus.

Esophageal fistula plug : The esophageal fistula plug consisted of two polypropylene plates, two sponges and waterproof strings. The esophageal fistula plug is shown in Figure 1B. The inner esophageal polypropylene plate $(8 \mathrm{~cm}$ long and $4 \mathrm{~cm}$ wide), which was fabricated to have a shape

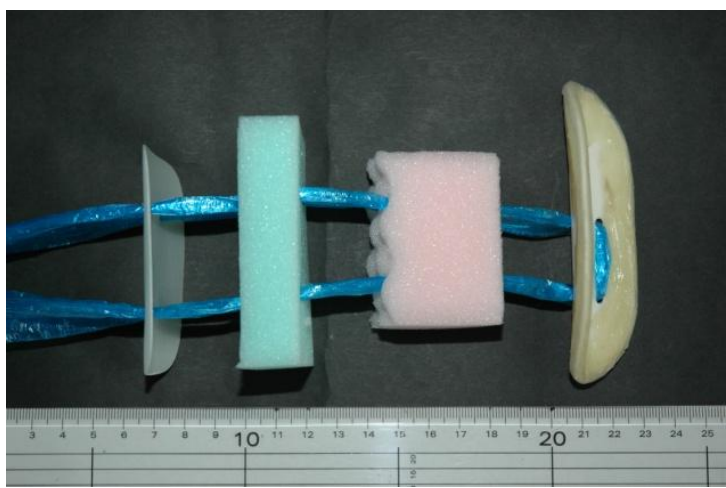

(B)

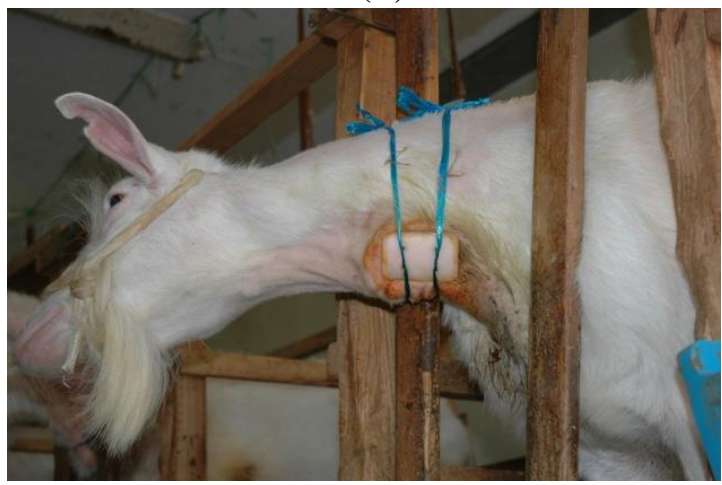

(D)

Figure 1. The esophageal fistula after completely recovered from surgery (A). The esophageal fistula plug for closing the esophageal fistula (B). The goat fitted with the esophageal fistula plug to close the esophageal fistula (C and D). 
similar to the esophageal lumen and coated with a thin layer of silicone on its edges, was put inside the esophagus. One of the sponges was inserted into the esophageal fistula and the other was used to cover the opening and together they filled the space between the two plates. The outer polypropylene plate $(7 \mathrm{~cm}$ long and $5.3 \mathrm{~cm}$ wide) covered over the two sponges. The waterproof strings connected the inner plate, two sponges and the outer plate tightly.

Esophageal cannula fabrication : The esophageal cannula for collecting the boluses consisted of two components. One polypropylene plate was $9 \mathrm{~cm}$ long, $4 \mathrm{~cm}$ wide and the other had the like-heart shape with $9 \mathrm{~cm}$ long and $8.5 \mathrm{~cm}$ wide. Both polypropylene plates were bent by putting them in boiling water for $5 \mathrm{~min}$ and then transferred immediately to ice water for $5 \mathrm{~min}$. The two curved polypropylene plates were joined together using an electric soldering iron to form an esophageal cannula (Figure 2A).

\section{Experimental design}

Experiment 1 - The effect of water availability during dry forage feeding on feed and water intake: The six esophageal- and ruminal-fistulated goats were divided into two groups (group A: three animals; group B: three animals). The experiment was carried out in accordance with a cross-over design. In the first experimental stage, group A was the control and was subjected to water deprivation under normal feeding conditions (WD). Group $\mathrm{B}$, as the treatment, received water availability under normal feeding conditions (WA). This was reversed in the second experimental stage in which group A was the treatment and received the WA while group B, as the control, was subjected to the WD.

In the WD control, the animals were deprived of water under normal feeding conditions. Animals in the WA treatment had ad libitum access to water under normal feeding conditions.

Experiment 2 - The effect of feed bolus removal during dry forage feeding on feed and water intake : Similar to experiment 1 , the animals were split into two groups (A and B). This experiment was conducted in accordance with a cross-over design. In the first experimental stage, group A was the control and received normal feeding conditions (NFC). Group B, as the treatment, was subjected to feed bolus removal (FBR). This was reversed in the second experimental stage in which group $\mathrm{A}$, as the treatment, was subjected to the FBR while group B was the control and received the NFC.

In the NFC control, the esophageal fistulae were always

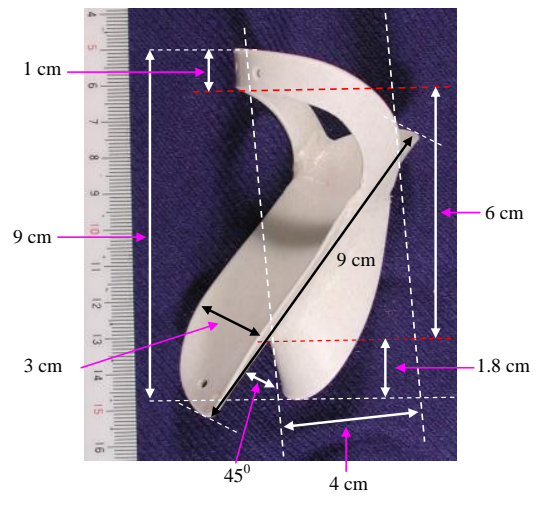

(A)

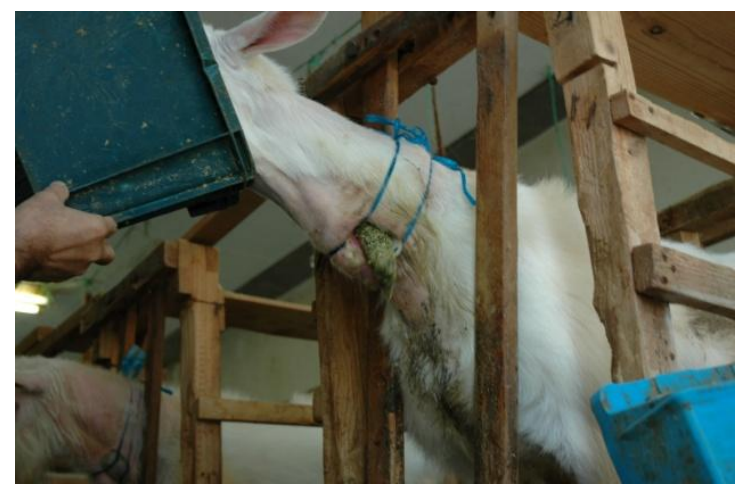

(C)

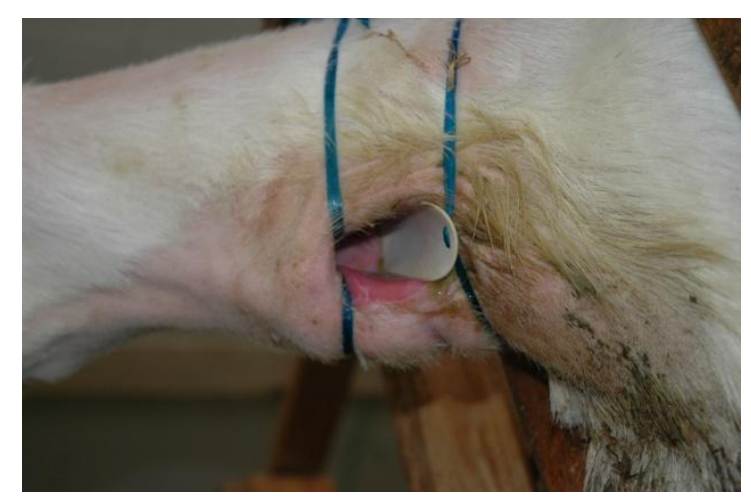

(B)

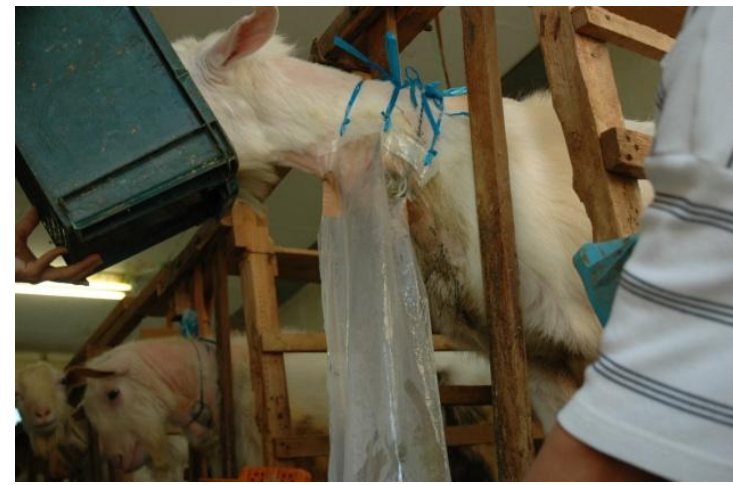

(D)

Figure 2. The sizes and shape of the esophageal cannula for collecting the boluses (A). The esophageal cannula for collecting the boluses was fitted into the esophageal fistula (B). The bolus output from the esophageal fistula was seen (C and D). 
closed by the esophageal fistula plugs and the animals ate dry forage in the normal manner but were deprived of water during feeding. However, in the FBR treatment, the goats were deprived of water during feeding and $3.5 \mathrm{~L}$ of artificial parotid saliva, a solution resembling parotid saliva (Sunagawa et al., 2008), was intraruminally infused to replenish saliva lost from the esophageal fistula during sham feeding. The intraruminal infusion of artificial parotid saliva was carried out with a bath tub pump and started concurrently with the commencement of feeding. The artificial parotid saliva had an osmolality of 272.1 $\mathrm{mOsmol} / \mathrm{L}, \mathrm{pH} 8.6$, and its concentrations of $\mathrm{Na}^{+}, \mathrm{K}^{+}, \mathrm{Cl}^{-}$, $\mathrm{HCO}_{3}^{-}$, and $\mathrm{HPO}_{4}^{-}$were $142.8 \mathrm{mmol} / \mathrm{L}, 8.8 \mathrm{mmol} / \mathrm{L}, 7.0$ $\mathrm{mmol} / \mathrm{L}, 145 \mathrm{mmol} / \mathrm{L}$, and $40 \mathrm{mmol} / \mathrm{L}$, respectively.

In both experiments, the controls and the treatments were carried out with each group at one week intervals to ensure that animals had recovered and to minimize any compounding effect from the previous treatments. In order to ascertain the physiological state of animals, heart rate, respiration rate, and rectal temperature were measured daily prior to the morning feeding period. Heart rate was measured by counting heart sounds with a stethoscope placed $5 \mathrm{~cm}$ behind the left olecranon. Respiration rate was measured by counting respiratory sounds with a stethoscope, and observing and counting thoracic movement that occurs in conjunction with respiration. Rectal temperature was measured using a veterinary thermometer inserted $10 \mathrm{~cm}$ into the rectum for approximately $10 \mathrm{~min}$.

One day before the start of each treatment, a polyethylene cannula (o.d. $1.50 \mathrm{~mm}$, No. 5, Imamura Gomu, Tokyo, Japan) was inserted into the jugular vein on one side of each goat for collecting blood samples. A three-way tap was attached to the end of each cannula. The cannula was sewn to the skin on the animal's neck and back to secure it and filled with heparin-saline $(50 \mathrm{IU} / \mathrm{ml})$ to prevent coagulation of the blood.

On the experimental days, before starting the FBR treatment of experiment 2, the plug for closing the esophageal fistula was removed and an esophageal cannula for collecting boluses was fitted into the fistula (Figure 2B). This allowed for the collection of all boluses swallowed and saliva secreted during the feeding period (Figure 2C and D).

On the experimental days, feeding time started at 10:00 $\mathrm{h}$ and finished at 12:00 $\mathrm{h}$ and during the $2 \mathrm{~h}$ feeding period, animals were fed ad libitum the roughly crushed alfalfa hay cubes. Following the completion of feeding, water was provided in a bucket and animals were allowed to drink freely for a period of $30 \mathrm{~min}$ (12:00 to 12:30 h).

The parameters measured in the present study were rate of eating, cumulative dry forage intake, rate of drinking, cumulative water intake, thirst level, hematocrit, plasma osmolality, plasma concentrations of total protein, glucose, $\mathrm{Na}, \mathrm{K}$, and $\mathrm{Cl}$, ruminal fluid $\mathrm{pH}$, osmolality, and concentrations of $\mathrm{Na}, \mathrm{K}$, and $\mathrm{Cl}$. The rate of eating ( $\mathrm{g}$ dry matter (DM)/10 min) and the cumulative dry forage intake (g DM) were measured during the $2 \mathrm{~h}$ of feeding (10:00 to $12: 00 \mathrm{~h}$ ). Eating rate was determined by placing the roughly crushed alfalfa hay cubes in a feed box attached to a scale and measuring the weight of the remaining feed every 10 min for the duration of the $2 \mathrm{~h}$ feeding period. The rate of drinking $(\mathrm{ml} / 15 \mathrm{~min})$ and the cumulative water intake $(\mathrm{ml})$ were measured during the $2 \mathrm{~h}$ feeding (10:00 to 12:00 h). Drinking rate was determined by placing $5 \mathrm{~L}$ of water in a bucket and measuring the volume of remaining water every $15 \mathrm{~min}$ for the duration of the $2 \mathrm{~h}$ feeding period. Thirst level $(\mathrm{ml} / 30 \mathrm{~min})$ was defined as water intake for $30 \mathrm{~min}$ following the conclusion of the $2 \mathrm{~h}$ feeding period.

Blood samples $(4 \mathrm{ml})$ were collected at 9:00, 10:00, $10: 15,10: 30,11: 00,11: 30,12: 00$ and 12:30 $\mathrm{h}$ through the polyethylene cannula. Prior to drawing the blood samples, a drop of heparin solution $(1,000 \mathrm{IU} / \mathrm{ml})$ was placed into a test tube. The blood samples were transferred to these test tubes, which were then placed on ice until plasma separation was carried out by centrifugation $(16,260 \times g, 10$ $\left.\min , 4^{\circ} \mathrm{C}\right)$.

Ruminal fluid samples $(30 \mathrm{ml})$ were collected at 9:00, $10: 00,10: 15,10: 30,11: 00,11: 30,12: 00$ and 12:30 h through the polyvinyl tube fitted in the ruminal fistula and put into test tubes placed on ice until ruminal fluid separation from sediments was carried out by centrifugation $\left(12,320 \times g, 10 \mathrm{~min}, 4^{\circ} \mathrm{C}\right)$.

All surgical and experimental procedures were approved by the Animal Experimental Ethics Committee of the University of the Ryukyus and were in compliance with the Japanese code of practice for the care and use of animals for scientific purposes.

\section{Chemical analysis of feeds}

The alfalfa hay cubes ( $84.3 \%$ dry matter) contained, on a dry matter basis, $18.7 \%$ crude protein, $2.4 \%$ crude fat, $29.7 \%$ crude fiber, $39.7 \%$ nitrogen-free extract (NFE), $45.9 \%$ neutral detergent fiber (NDF), 36.6\% acid detergent fiber $(\mathrm{ADF}), 0.10 \% \mathrm{Na}, 2.39 \% \mathrm{~K}, 0.47 \% \mathrm{Cl}, 1.40 \% \mathrm{Ca}$, $0.29 \% \mathrm{Mg}$, and $0.23 \% \mathrm{P}$. The proportion of each ingredient in the concentrated beef cattle feed was $48 \%$ maize, $24 \%$ sorghum, $1 \%$ barley, $3.5 \%$ soybean meal, $9.5 \%$ rapeseed meal, $6.0 \%$ wheat bran, $5.0 \%$ rice polishings, $0.5 \%$ molasses, $1.4 \%$ calcium carbonate, $0.5 \%$ alfalfa meal, $0.5 \%$ sodium chloride, $0.05 \%$ dicalcium phosphate, and $0.05 \%$ vitamin trace minerals premix. The concentrated beef cattle feed (86.9\% dry matter) contained, on a dry matter basis, $13.4 \%$ crude protein, $3.6 \%$ crude fat, $3.7 \%$ crude fiber, $71.0 \%$ nitrogen-free extract (NFE), $14.6 \%$ neutral detergent fiber (NDF), 5.4\% acid detergent fiber (ADF), $0.25 \% \mathrm{Na}$, $0.71 \% \mathrm{~K}, 0.31 \% \mathrm{Cl}, 0.78 \% \mathrm{Ca}, 0.25 \% \mathrm{Mg}$, and $0.48 \% \mathrm{P}$.

Alfalfa hay cubes and concentrated beef cattle feed were 
subjected to draught drying $\left(70^{\circ} \mathrm{C}, 24 \mathrm{~h}\right)$ and were then ground with a Wiley mill (type 40-525P, Ikemoto, Rika Kougyou, Tokyo, Japan). The diameter of the holes of the mill grid was $1 \mathrm{~mm}$. The chemical components of the feeds were quantified using the procedures described by the AOAC (1990). The chemical component analysis was conducted in triplicate using a total of three samples for each type of feed. The dry matter (DM) content was quantified by oven drying at $135 \pm 2^{\circ} \mathrm{C}$ for $2 \mathrm{~h}$. The crude protein content was calculated from the nitrogen content of the feed determined by a Kjeldhal technique (AOAC, 1990). The crude fat content of feed was determined by continuous extraction with ethyl ether for $16 \mathrm{~h}$ using a Soxhlet extraction apparatus. Crude fiber was determined by subjecting the residue from ether extraction to successive treatments with boiling sulfuric acid (1.25\%) and sodium hydroxide (1.25\%). Nitrogen-free extract (NFE) was calculated by subtraction of the sum of moisture, ash, crude protein, crude fat and crude fiber content from 100. The acid detergent fiber (ADF) and neutral detergent fiber (NDF) were determined as described Van Soest et al. (1991). For concentrated beef cattle feed, prior to adding the neutral detergent solution, the sample was boiled and pre-treated with $\alpha$-amylase at $40^{\circ} \mathrm{C}$. The samples were charred, ignited and reduced to ash at $550^{\circ} \mathrm{C}$ in an electric furnace. The mineral content of the ash was then measured using an atomic absorption flame emission spectrophotometer (AA6200, Shimadzu Corporation, Kyoto, Japan). The $\mathrm{Cl}$ content was measured using ion chromatographic methods.

\section{Biochemical analysis}

Blood samples were placed in capillary tubes and centrifuged using a hematocrit centrifuge (HC-12A, Tomy Seiko, Tokyo, Japan; $12,851 \times g, 5 \mathrm{~min})$ to determine hematocrit by hematocrit reader (Tomy Seiko, Tokyo, Japan). Plasma total protein concentration and osmolality were measured using a refractometer (Atago, Tokyo, Japan) and an osmometer (OM-6010, Kyoto Daiichi Kagaku, Kyoto, Japan), respectively. Plasma glucose concentration was measured using a Spotchem EZ (SP-4430, Arkray, Tokyo, Japan). The plasma concentrations of $\mathrm{Na}, \mathrm{K}$, and $\mathrm{Cl}$ were measured using a Spotchem EL (SE-1520, Arkray, Kyoto, Japan).

Ruminal fluid was analyzed for osmolality with an osmometer (OM-6010, Kyoto Daiichi Kagaku, Kyoto, Japan), for $\mathrm{pH}$ and $\mathrm{Cl}$ concentration by a $\mathrm{pH} / \mathrm{Ion}$ meter F-53 (Horiba Ltd., Kyoto, Japan), and for concentrations of $\mathrm{Na}$ and $\mathrm{K}$ with an atomic absorption flame emission spectrophotometer (AA-6200, Shimadzu Corporation, Kyoto, Japan).

\section{Statistical analysis}

Factorial analysis (treatment, animal) of variance was performed and subsequent $t$-tests were used to determine the significance of treatment effects. For statistical analysis, General Linear Model (GLM) procedures (SAS Inst., Inc., Cary, NC, 1990) were adopted.

All data were analyzed using the following model:

$$
\mathrm{Y}_{\mathrm{ijklm}}=\mu+\mathrm{G}_{\mathrm{i}}+\mathrm{A}_{\mathrm{ij}}+\mathrm{T}_{\mathrm{k}}+\mathrm{P}_{\mathrm{m}}+\varepsilon_{\mathrm{ijklm}}
$$

Where $\mathrm{Y}_{\mathrm{ijklm}}=$ the measured variable on the $1^{\text {th }}$ replication of the $\mathrm{j}^{\text {th }}$ animal within the $\mathrm{i}^{\text {th }}$ group, the $\mathrm{k}^{\text {th }}$ treatment and the $m^{\text {th }}$ period; $\mu=$ the overall mean; $G_{i}=$ the effect of the $i^{\text {th }}$ group; $A_{i j}=$ the effect of the $j^{\text {th }}$ animal within the $i^{\text {th }}$ group; $\mathrm{T}_{\mathrm{k}}=$ the effect of the $\mathrm{k}^{\text {th }}$ treatment; $\mathrm{P}_{\mathrm{m}}=$ the effect of the $\mathrm{m}^{\text {th }}$ period; $\varepsilon_{\mathrm{ijklm}}=$ the random error effect.

\section{RESULTS}

\section{Experiment 1 - The effect of water availability during dry forage feeding on feed and water intake}

Physiological parameters : The mean values of heart rate, respiration rate, and rectal temperature in the WD control and the WA treatment were 76.0 \pm 2.97 and $77.0 \pm 3.26$ beats/min, $18.7 \pm 0.42$ and $17.3 \pm 0.42$ breaths/min, and $38.5 \pm 0.15$ and $38.2 \pm 0.14^{\circ} \mathrm{C}$, respectively. There were no significant differences between the WD control and the WA treatment in the physiological parameters.

Rate of eating and cumulative dry forage intake : Figure 3 shows the effect of WA during dry forage feeding on rate of eating and cumulative dry forage intake. Eating rates in both the WD control and the WA treatment decreased rapidly in the first $30 \mathrm{~min}$ of feeding (0 to $10 \mathrm{~min}$, $491.8 \pm 36.01$ and $494.6 \pm 25.63 \mathrm{~g} ; 20$ to $30 \mathrm{~min}, 123.6 \pm 25.26$ and $168.6 \pm 45.03 \mathrm{~g}$, respectively) and subsequently declined gradually to very low rates (ranged from $23.9 \pm 11.60$ to $127.9 \pm 24.86 \mathrm{~g} / 10 \mathrm{~min}$ and $36.5 \pm 11.03$ to $140.5 \pm 22.48 \mathrm{~g} / 10$ min, respectively) for the remainder of the $2 \mathrm{~h}$ feeding period. Compared with the WD control, eating rates in the WA treatment were significantly higher $(p<0.05)$ at the 90 min interval only.

In comparison with the WD control $(1,459.8 \pm 146.57 \mathrm{~g} / 2 \mathrm{~h})$, cumulative dry forage intake in the WA treatment $(1,847.6 \pm 165.23 \mathrm{~g} / 2 \mathrm{~h})$ was $26.6 \%$ higher $(\mathrm{p}<0.01)$ upon conclusion of the $2 \mathrm{~h}$ feeding period.

Rate of drinking and cumulative water intake : Figure 4 shows the rate of drinking and cumulative water intake in the WA treatment. Drinking rate recorded indicated the animals began consuming very small amounts of water 30 min after the start of feeding. Drinking rate reached the level of $483.3 \pm 225.71 \mathrm{ml} / 15 \mathrm{~min}$ at $90 \mathrm{~min}$ interval and peaked at $120 \mathrm{~min}$ interval with a recorded rate of $716.7 \pm 138.24 \mathrm{ml} / 15 \mathrm{~min}$. Water intake focused mainly on the second hour of the $2 \mathrm{~h}$ feeding period and cumulative 

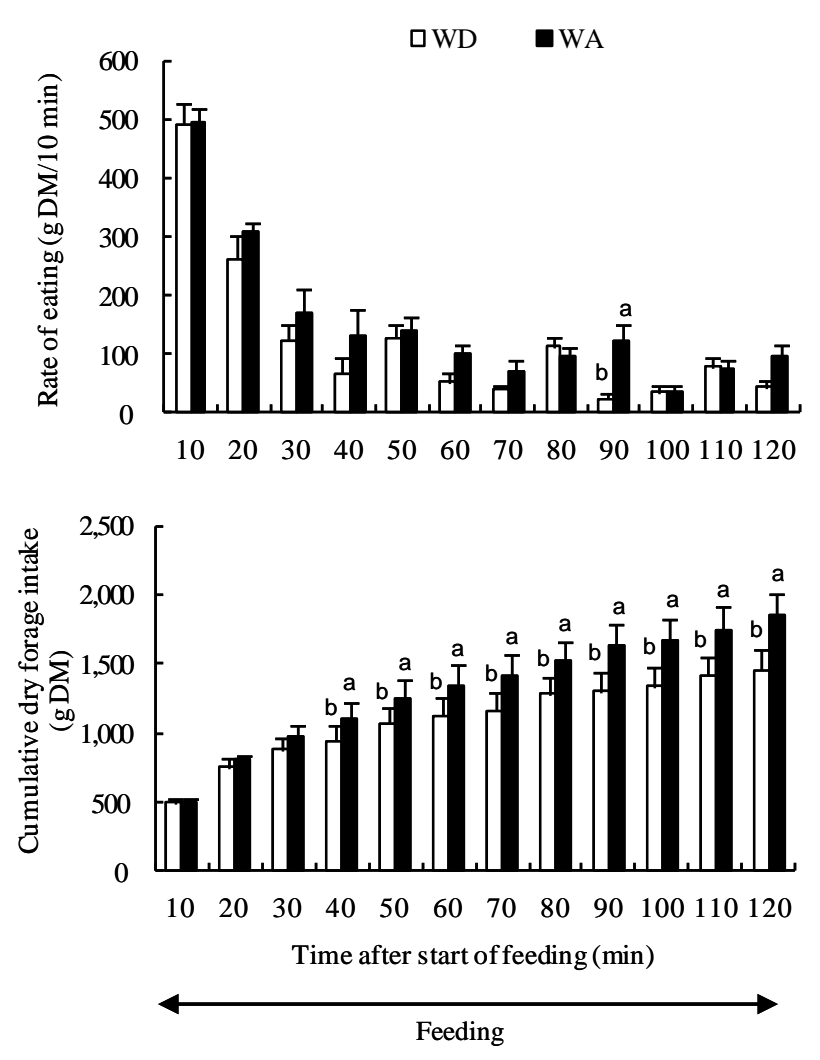

Figure 3. The effect of water availability (WA) during dry forage feeding on rate of eating and cumulative dry forage intake. Values are means \pm SE of 6 large-type goats. ${ }^{a, b}$ Means with different superscript are significantly different $(\mathrm{p}<0.05)$ from water deprivation (WD).

water intake was $1,983.3 \pm 310.56 \mathrm{ml}$ upon conclusion of the $2 \mathrm{~h}$ feeding period.

Hematocrit, plasma concentrations of total protein and glucose : Table 1 presents the effect of WA during dry forage feeding on hematocrit, plasma concentrations of total protein and glucose. Hematocrit and plasma total protein concentrations in both the WD control and the WA
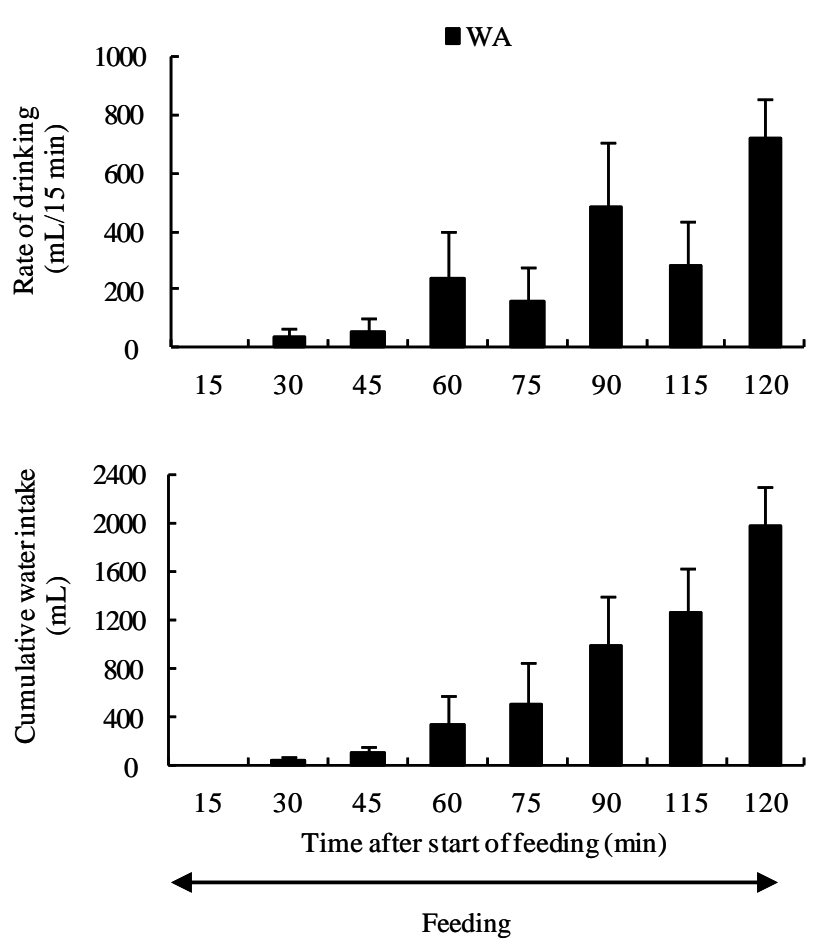

Figure 4. Rate of drinking and cumulative water intake in water availability (WA) treatment under normal feeding conditions.

treatment increased rapidly during the first $15 \mathrm{~min}$ after the start of feeding. Subsequently, hematocrit and plasma total protein concentrations gradually decreased in both the WD control and the WA treatment for the remainder of the $2 \mathrm{~h}$ feeding period. There were no significant differences between the WD control and the WA treatment in terms of hematocrit during the $2 \mathrm{~h}$ feeding period. Compared with the WD control, plasma total protein concentrations in the WA treatment were significantly higher $(\mathrm{p}<0.05)$ at 15 and $120 \mathrm{~min}$ intervals. Plasma glucose concentrations in the WD control were not significantly different compared to the WA treatment during the $2 \mathrm{~h}$ feeding period.

Table 1. The effect of water availability during dry forage feeding on hematocrit, plasma concentrations of total protein, glucose, Na, K, and $\mathrm{Cl}$ under normal feeding conditions

\begin{tabular}{|c|c|c|c|c|c|c|c|c|c|c|c|c|c|c|c|c|c|c|}
\hline \multirow{2}{*}{$\begin{array}{l}\text { Time before } \\
\text { and after } \\
\text { start of } \\
\text { feeding ( } \mathrm{min})\end{array}$} & \multicolumn{3}{|c|}{$\begin{array}{c}\text { Hematocrit } \\
(\%)\end{array}$} & \multicolumn{3}{|c|}{$\begin{array}{l}\text { Plasma total protein } \\
\text { (g/dl) }\end{array}$} & \multicolumn{3}{|c|}{$\begin{array}{l}\text { Plasma glucose } \\
\text { (mg/dl) }\end{array}$} & \multicolumn{3}{|c|}{$\begin{array}{l}\text { Plasma Na } \\
(\mathrm{mmol} / \mathrm{L})\end{array}$} & \multicolumn{3}{|c|}{$\begin{array}{l}\text { Plasma K } \\
(\mathrm{mmol} / \mathrm{L})\end{array}$} & \multicolumn{3}{|c|}{$\begin{array}{c}\text { Plasma Cl } \\
(\mathrm{mmol} / \mathrm{L})\end{array}$} \\
\hline & WD & WA & $\mathrm{SE}$ & WD & WA & SE & WD & WA & SE & WD & WA & SE & WD & WA & SE & WD & WA & SE \\
\hline-60 & 25.3 & 25.3 & 0.90 & 6.8 & 6.8 & 0.30 & 71.5 & 70.8 & 4.45 & 138.7 & 138.7 & 1.25 & 4.6 & 4.6 & 0.16 & 100.0 & 98.3 & 1.17 \\
\hline 0 & 25.2 & 24.5 & 1.09 & 6.8 & 6.7 & 0.31 & 69.3 & 69.2 & 3.47 & 137.8 & 137.8 & 1.65 & 4.6 & 4.7 & 0.23 & 99.5 & 99.0 & 0.99 \\
\hline 15 & 31.1 & 30.9 & 1.26 & $7.8^{\mathrm{b}}$ & $8.1^{\mathrm{a}}$ & 0.44 & 70.5 & 72.2 & 3.36 & 139.2 & 139.8 & 0.99 & 4.7 & 4.8 & 0.18 & 104.2 & 104.2 & 1.39 \\
\hline 30 & 30.6 & 30.4 & 1.19 & 7.6 & 7.8 & 0.42 & 68.3 & 70.8 & 4.02 & 139.3 & 140.8 & 1.57 & 4.6 & 4.7 & 0.21 & 105.7 & 104.2 & 1.73 \\
\hline 60 & 29.0 & 29.7 & 1.09 & 7.4 & 7.6 & 0.39 & 68.8 & 68.5 & 3.58 & 142.8 & 142.5 & 1.07 & 4.8 & 4.8 & 0.25 & 105.8 & 104.3 & 1.29 \\
\hline 90 & 28.6 & 29.3 & 1.18 & 7.2 & 7.6 & 0.35 & 70.5 & 69.3 & 3.05 & 143.7 & 141.8 & 1.59 & 4.9 & 5.0 & 0.31 & 106.7 & 106.2 & 1.63 \\
\hline 120 & 28.8 & 29.4 & 1.23 & $7.3^{\mathrm{b}}$ & $7.6^{\mathrm{a}}$ & 0.37 & 72.8 & 69.7 & 2.88 & 146.8 & 145.2 & 1.31 & 4.6 & 4.7 & 0.27 & 108.7 & 106.5 & 1.58 \\
\hline 150 & 27.0 & 26.9 & 1.29 & 7.0 & 7.1 & 0.30 & 71.7 & 71.0 & 2.95 & 144.8 & 145.2 & 1.18 & 4.5 & 4.6 & 0.19 & 105.8 & 106.2 & 1.36 \\
\hline
\end{tabular}

WD = Water deprivation; WA = Water availability. Values are means of 6 large-type goats; SE = Pooled standard error.

${ }^{\mathrm{a}, \mathrm{b}}$ Means in the same row bearing different superscripts differ $(\mathrm{p}<0.05)$. 
Plasma concentrations of $\mathrm{Na}, \mathrm{K}$ and $\mathrm{Cl}$ : The effect of WA during dry forage feeding on plasma concentrations of $\mathrm{Na}, \mathrm{K}$ and $\mathrm{Cl}$ is shown in Table 1. Plasma concentrations of $\mathrm{Na}$ and $\mathrm{Cl}$ in both the WD control and the WA treatment increased gradually during the $2 \mathrm{~h}$ feeding period. Compared with the WD control, plasma concentrations of $\mathrm{Na}$ and $\mathrm{Cl}$ in the WA treatment were not significantly different for the duration of the $2 \mathrm{~h}$ feeding period. Plasma $\mathrm{K}$ concentrations in the WA treatment changed similar to those in the WD control. There were no significant differences between the control and the treatment in terms of plasma $\mathrm{K}$ concentrations before and during the $2 \mathrm{~h}$ feeding period.

Osmolality of plasma and ruminal fluid : Figure 5 shows the effect of WA during dry forage feeding on osmolality of plasma and ruminal fluid. Plasma osmolality in both the WD control and the WA treatment increased gradually and reached the level of $314.5 \pm 1.95$ and $306.7 \pm 2.53 \mathrm{mOsmol} / \mathrm{L}$, respectively, upon conclusion of the $2 \mathrm{~h}$ feeding period. Compared with the WD control, plasma osmolality in the WA treatment was lower but there were no significant differences for the duration of the $2 \mathrm{~h}$ feeding period.

Ruminal fluid osmolality in both the WD control and the WA treatment increased progressively as feeding period elapsed and reached the highest level of 503.2 \pm 15.94 and $484.3 \pm 14.49 \mathrm{mOsmol} / \mathrm{L}$, respectively, upon conclusion of the $2 \mathrm{~h}$ feeding period. Compared with the WD control, ruminal fluid osmolality in the WA treatment was not significantly different for the duration of the $2 \mathrm{~h}$ feeding period. However, ruminal fluid osmolality in the WA treatment was higher $(\mathrm{p}<0.05)$ compared with that in the WD control upon conclusion of the 30 min drinking period.

Ruminal fluid $\mathrm{pH}$ and concentrations of $\mathrm{Na}, \mathrm{K}$ and $\mathrm{Cl}$ : Table 2 presents the effect of WA during dry forage feeding on ruminal fluid $\mathrm{pH}$ and concentrations of $\mathrm{Na}, \mathrm{K}$ and $\mathrm{Cl}$. Ruminal fluid $\mathrm{pH}$ in both the WD control and the WA
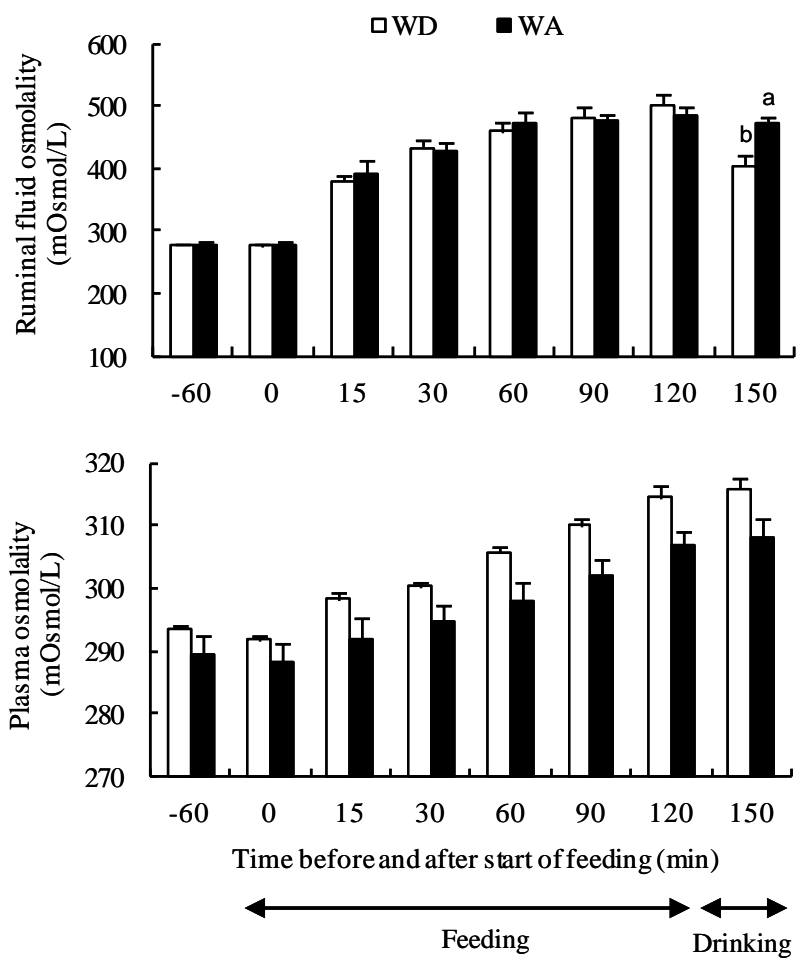

Figure 5. The effect of water availability (WA) during dry forage feeding on osmolality of plasma and ruminal fluid. Values are means \pm SE of 6 large-type goats. ${ }^{\mathrm{a}, \mathrm{b}}$ Means with different superscript are significantly different $(\mathrm{p}<0.05)$ from water deprivation $(\mathrm{WD})$.

treatment decreased gradually and reached the lowest level of $6.08 \pm 0.07$ and $6.07 \pm 0.09$, respectively, at $150 \mathrm{~min}$ interval. Compared with the WD control, ruminal fluid $\mathrm{pH}$ in the WA treatment was not significantly different for the duration of the $2 \mathrm{~h}$ feeding period.

In comparison with the WD control, ruminal fluid concentrations of $\mathrm{Na}$ in the WA treatment were not significantly different over the $2 \mathrm{~h}$ feeding period.

Ruminal fluid concentrations of $\mathrm{K}$ in both the WD control and the WA treatment tended to be increased

Table 2. The effect of water availability during dry forage feeding on ruminal fluid $\mathrm{pH}$ and concentrations of $\mathrm{Na}$, $\mathrm{K}$, and $\mathrm{Cl}$ under normal feeding conditions

\begin{tabular}{|c|c|c|c|c|c|c|c|c|c|c|c|c|}
\hline \multirow{2}{*}{$\begin{array}{l}\text { Time before and } \\
\text { after start of } \\
\text { feeding (min) }\end{array}$} & \multicolumn{3}{|c|}{ Ruminal fluid $\mathrm{pH}$} & \multicolumn{3}{|c|}{$\begin{array}{l}\text { Ruminal fluid } \mathrm{Na} \\
\qquad(\mathrm{mmol} / \mathrm{L})\end{array}$} & \multicolumn{3}{|c|}{$\begin{array}{l}\text { Ruminal fluid } \mathrm{K} \\
\text { (mmol/L) }\end{array}$} & \multicolumn{3}{|c|}{$\begin{array}{l}\text { Ruminal fluid } \mathrm{Cl} \\
\qquad(\mathrm{mmol} / \mathrm{L})\end{array}$} \\
\hline & WD & WA & SE & WD & WA & SE & WD & WA & SE & WD & WA & SE \\
\hline-60 & 6.93 & 6.94 & 0.08 & 140.5 & 143.9 & 15.01 & $70.2^{\mathrm{a}}$ & $47.5^{\mathrm{b}}$ & 8.48 & 33.5 & 36.2 & 2.57 \\
\hline 0 & 6.93 & 6.96 & 0.06 & 136.1 & 144.6 & 15.99 & 65.9 & 53.3 & 10.24 & 37.3 & 35.5 & 2.63 \\
\hline 15 & 6.42 & 6.46 & 0.08 & 130.8 & 146.6 & 15.28 & $89.2^{\mathrm{a}}$ & $77.3^{\mathrm{b}}$ & 9.39 & 57.0 & 57.0 & 3.62 \\
\hline 30 & 6.32 & 6.36 & 0.08 & 137.0 & 153.2 & 14.93 & $109.4^{\mathrm{a}}$ & $87.4^{\mathrm{b}}$ & 12.47 & 65.5 & 68.1 & 5.58 \\
\hline 60 & 6.29 & 6.29 & 0.09 & 137.2 & 156.7 & 15.20 & 117.0 & 101.8 & 13.89 & 70.7 & 73.4 & 6.50 \\
\hline 90 & 6.25 & 6.21 & 0.08 & 139.1 & 143.2 & 16.47 & $125.3^{\mathrm{a}}$ & $100.6^{\mathrm{b}}$ & 15.00 & 74.0 & 74.6 & 5.60 \\
\hline 120 & 6.15 & 6.16 & 0.08 & 135.2 & 141.3 & 17.32 & $124.2^{\mathrm{a}}$ & $100.6^{\mathrm{b}}$ & 14.65 & 73.1 & 72.8 & 4.26 \\
\hline 150 & 6.08 & 6.07 & 0.11 & 114.2 & 124.5 & 19.74 & 107.1 & 97.4 & 12.04 & 59.8 & 65.0 & 5.80 \\
\hline
\end{tabular}

$\mathrm{WD}=$ Water deprivation; WA = Water availability. Values are means of 6 large-type goats; $\mathrm{SE}=$ Pooled standard error.

${ }^{\mathrm{a}, \mathrm{b}}$ Means in the same row bearing different superscripts differ $(\mathrm{p}<0.05)$. 
gradually as feeding period elapsed. Compared with the WD control, ruminal fluid concentrations of $\mathrm{K}$ in the WA treatment were significantly lower $(\mathrm{p}<0.05)$ at $-60,15,30$, 90 and $120 \mathrm{~min}$ intervals.

Ruminal fluid concentrations of $\mathrm{Cl}$ in the WA treatment changed similar to those in the WD control during the $2 \mathrm{~h}$ feeding period. Compared with the WD control, ruminal fluid concentrations of $\mathrm{Cl}$ in the WA treatment were not significantly different over the $2 \mathrm{~h}$ feeding period.

\section{Experiment 2 - The effect of feed bolus removal during dry forage feeding on feed and water intake}

The results of esophageal fistulation and maintenance of esophageal fistulae : Esophageal fistulation was successfully performed on eleven large-type goats. Postsurgery recovery was relatively rapid. The clinical signs of inflammation, infection, hemorrhage, tissue necrosis, and suture abscess in the surgical site were not observed after the fistulation procedure had been performed. When both edges of the incised esophagus and skin were sutured together tightly as in the second step operation, the connective tissues had developed to unite the incised skin and esophageal wall to form a scar tissue ring. The time for the scar tissue ring to completely develop was approximately 20 to 30 days after surgery depending on each animal. Figure 1A shows the esophageal fistula after complete recovery from the surgery. The goats were able to eat several kinds of feed including long hay, roughly crushed alfalfa hay cubes without any leakage or other problems when the esophageal fistulae were closed by the esophageal fistula plugs.

The sizes of an esophageal fistula plug that were designed and fabricated as shown in Figure 1B were fitted to the esophageal fistula of each goat. The esophageal fistula plug was easily inserted into or removed from the esophageal fistula. When the esophageal fistula plug was fitted into the esophageal fistula, it closed completely the esophageal fistula and did not cause any injury to the esophageal lumen. There was no observed trouble in deglutition and rumination and there was no leakage of saliva or ruminal fluid.

The esophageal fistulae of goats were always closed by the esophageal fistula plugs (Figure 1C and D) except when sham feeding experiments were conducted. The daily maintenance of esophageal fistulae did not require any special care. The esophageal fistula plugs were removed and washed every two days, and the esophageal fistulae were sterilized by tincture of iodine. After the esophageal fistula plugs were sterilized, they were once again fitted into the esophageal fistulae. When the sponges between two polypropylene plates of the esophageal fistula plug were broken, it was necessary to replace them to avoid leaking of saliva and ruminal fluid during deglutition and rumination.
Because of the scheduled care as described above, the fistulae were successfully maintained and the esophagealfistulated animals remained in good health for long-term experiments (four years).

Physiological parameters : The mean values of heart rate, respiration rate, and rectal temperature in the NFC control and the FBR treatment were 76.0 \pm 2.97 and $72.0 \pm 3.10$ beats/min, $18.7 \pm 0.42$ and $16.7 \pm 0.99$ breaths/min, and $38.5 \pm 0.15$ and $38.1 \pm 0.15^{\circ} \mathrm{C}$, respectively. There were no significant differences between the NFC control and the FBR treatment in the physiological parameters.

Rate of eating and cumulative dry forage intake : Figure 6 shows the effect of FBR during dry forage feeding on rate of eating and cumulative dry forage intake. Eating rates in the FBR treatment decreased slowly in the first $30 \mathrm{~min}$ of feeding ( 0 to $10 \mathrm{~min}, 512.8 \pm 41.21 \mathrm{~g} ; 20$ to $30 \mathrm{~min}$, $311.9 \pm 19.22 \mathrm{~g})$ and then remained at high rates during the remaining time of the $2 \mathrm{~h}$ feeding period. Meanwhile, eating rates in the NFC control decreased rapidly in the first 30 min of feeding (0 to $10 \mathrm{~min}, 491.8 \pm 36.01 \mathrm{~g} ; 20$ to $30 \mathrm{~min}$, $123.6 \pm 25.26 \mathrm{~g}$ ) and subsequently declined gradually to very low rates (ranged from $23.9 \pm 11.60$ to $127.9 \pm 24.86 \mathrm{~g} / 10$
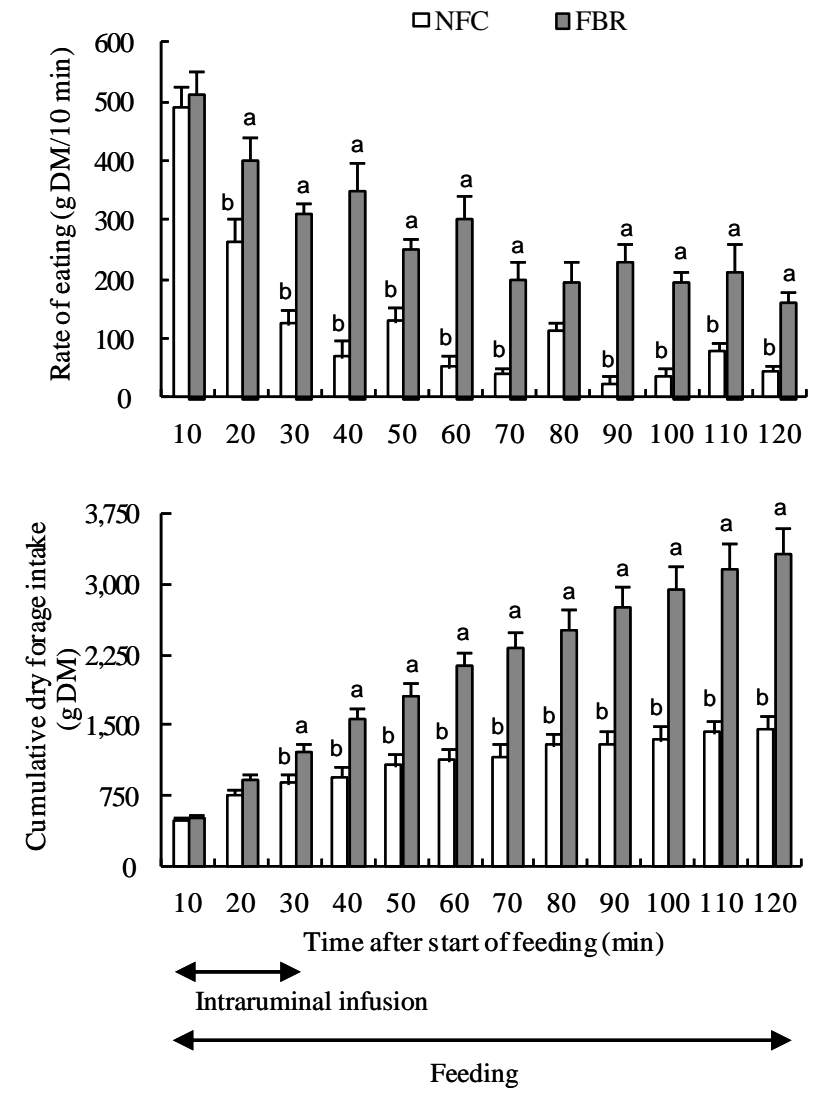

Figure 6. The effect of feed bolus removal (FBR) during dry forage feeding on rate of eating and cumulative dry forage intake. Values are means \pm SE of 6 large-type goats. ${ }^{a, b}$ Means with different superscript are significantly different $(p<0.05)$ from normal feeding conditions (NFC). 
min) for the rest of the $2 \mathrm{~h}$ feeding period. Compared with the NFC control, eating rates in the FBR treatment were significantly higher $(\mathrm{p}<0.05)$ from $20 \mathrm{~min}$ after the start of feeding to the end of the $2 \mathrm{~h}$ feeding period except at 80 min interval.

In comparison with the NFC control $(1,459.8 \pm 146.57$ $\mathrm{g} / 2 \mathrm{~h}$ ), cumulative dry forage intake in the FBR treatment $(3,332.7 \pm 270.32 \mathrm{~g} / 2 \mathrm{~h})$ was $128.3 \%$ higher $(\mathrm{p}<0.01)$ upon conclusion of the $2 \mathrm{~h}$ feeding period.

Thirst level : Figure 7 shows the effect of FBR during dry forage feeding on thirst level. In comparison with the NFC control $(3,658.3 \pm 291.95 \mathrm{ml} / 30 \mathrm{~min})$, thirst level in the FBR treatment $(633.3 \pm 189.15 \mathrm{ml} / 30 \mathrm{~min})$ was $82.7 \%$ less $(\mathrm{p}<0.01)$ upon conclusion of the 30 min drinking period.

Hematocrit, plasma concentrations of total protein and glucose : Table 3 presents the effect of FBR during dry forage feeding on hematocrit, plasma concentrations of total protein and glucose. Hematocrit and plasma total protein concentrations in both the NFC control and the FBR treatment increased rapidly in the first $15 \mathrm{~min}$ after the start of feeding. Subsequently, hematocrit and plasma total protein concentrations decreased gradually in the NFC control while remaining at high level in the FBR treatment for the remainder of the $2 \mathrm{~h}$ feeding period. Compared with the NFC control, hematocrit and plasma total protein concentrations in the FBR treatment were significantly higher $(\mathrm{p}<0.05)$ from 60 to $120 \mathrm{~min}$ intervals and over the 2 $\mathrm{h}$ feeding period, respectively.

Plasma glucose concentrations in the FBR treatment were significantly lower $(\mathrm{p}<0.05)$ than those in the NFC control at 0 and $120 \mathrm{~min}$ intervals.

Plasma concentrations of $\mathrm{Na}, \mathrm{K}$ and $\mathrm{Cl}$ : The effect of FBR during dry forage feeding on plasma concentrations of $\mathrm{Na}, \mathrm{K}$ and $\mathrm{Cl}$ is shown in Table 3. Plasma concentrations of $\mathrm{Na}$ and $\mathrm{Cl}$ in the NFC control increased gradually while they mostly remained unchanged in the FBR treatment during the $2 \mathrm{~h}$ feeding period. Compared with the NFC

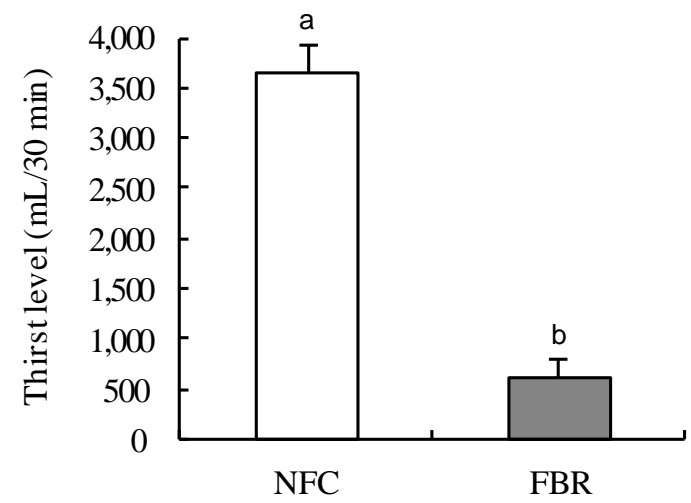

Figure 7. The effect of feed bolus removal (FBR) during dry forage feeding on thirst level. Values are means \pm SE of 6 largetype goats. ${ }^{\mathrm{a}, \mathrm{b}}$ Means with different superscript are significantly different $(\mathrm{p}<0.01)$ from normal feeding conditions $(\mathrm{NFC})$.

control, plasma concentrations of $\mathrm{Na}$ in the FBR treatment were significantly higher $(\mathrm{p}<0.05)$ at $-60,0$, and $30 \mathrm{~min}$ intervals but they were significantly lower $(\mathrm{p}<0.05)$ at 90 , 120 , and 150 min intervals. Plasma concentrations of $\mathrm{Cl}$ in the FBR treatment were significantly lower $(\mathrm{p}<0.05)$ compared with those in the NFC control at 120 and 150 min intervals.

Plasma K concentrations in the NFC control and the FBR treatment were similar. There were no significant differences between the control and the treatment in terms of plasma $\mathrm{K}$ concentrations for the duration of the $2 \mathrm{~h}$ feeding period.

Osmolality of plasma and ruminal fluid : Figure 8 shows the effect of FBR during dry forage feeding on osmolality of plasma and ruminal fluid. Plasma osmolality in the NFC control increased gradually and reached the level of $314.5 \pm 1.95 \mathrm{mOsmol} / \mathrm{L}$ upon conclusion of the $2 \mathrm{~h}$ feeding period. Meanwhile, plasma osmolality in the FBR treatment increased very slowly and peaked (300.2 \pm 0.95 $\mathrm{mOsmol} / \mathrm{L}$ ) upon conclusion of the $2 \mathrm{~h}$ feeding period.

Table 3. The effect of feed bolus removal during dry forage feeding on hematocrit, plasma concentrations of total protein, glucose, Na, $\mathrm{K}$, and $\mathrm{Cl}$

\begin{tabular}{|c|c|c|c|c|c|c|c|c|c|c|c|c|c|c|c|c|c|c|}
\hline \multirow{2}{*}{$\begin{array}{l}\text { Time before } \\
\text { and after start } \\
\text { of feeding } \\
\text { (min) }\end{array}$} & \multicolumn{3}{|c|}{$\begin{array}{c}\text { Hematocrit } \\
(\%)\end{array}$} & \multicolumn{3}{|c|}{$\begin{array}{l}\text { Plasma total protein } \\
\qquad(\mathrm{g} / \mathrm{dl})\end{array}$} & \multicolumn{3}{|c|}{$\begin{array}{l}\text { Plasma glucose } \\
\text { (mg/dl) }\end{array}$} & \multicolumn{3}{|c|}{$\begin{array}{l}\text { Plasma Na } \\
(\mathrm{mmol} / \mathrm{L})\end{array}$} & \multicolumn{3}{|c|}{$\begin{array}{l}\text { Plasma K } \\
(\mathrm{mmol} / \mathrm{L})\end{array}$} & \multicolumn{3}{|c|}{$\begin{array}{c}\text { Plasma Cl } \\
(\mathrm{mmol} / \mathrm{L})\end{array}$} \\
\hline & NFC & FBR & SE & NFC & FBR & $\mathrm{SE}$ & NFC & FBR & SE & NFC & FBR & SE & NFC & FBR & SE & NFC & FBR & SE \\
\hline-60 & 25.3 & 25.9 & 1.22 & 6.8 & 7.1 & 0.30 & 71.5 & 66.0 & 3.22 & $138.7^{b}$ & $140.8^{\mathrm{a}}$ & 1.07 & 4.6 & 4.6 & 0.23 & 100.0 & 101.0 & 1.21 \\
\hline 0 & 25.2 & 26.1 & 1.29 & 6.8 & 7.1 & 0.31 & $69.3^{\mathrm{a}}$ & $66.2^{\mathrm{b}}$ & 2.10 & $137.8^{\mathrm{b}}$ & $140.5^{\mathrm{a}}$ & 0.90 & 4.6 & 4.7 & 0.17 & $99.5^{\mathrm{b}}$ & $100.3^{\mathrm{a}}$ & 0.75 \\
\hline 15 & 31.1 & 33.8 & 1.76 & $7.8^{\mathrm{b}}$ & $8.4^{\mathrm{a}}$ & 0.42 & 70.5 & 67.5 & 3.28 & 139.2 & 141.3 & 1.10 & 4.7 & 4.8 & 0.15 & 104.2 & 104.8 & 0.96 \\
\hline 30 & 30.6 & 34.3 & 1.98 & $7.6^{\mathrm{b}}$ & $8.6^{\mathrm{a}}$ & 0.41 & 68.3 & 66.3 & 2.74 & $139.3^{\mathrm{b}}$ & $140.8^{\mathrm{a}}$ & 1.69 & 4.6 & 4.7 & 0.19 & 105.7 & 105.0 & 1.74 \\
\hline 60 & $29.0^{\mathrm{b}}$ & $34.0^{\mathrm{a}}$ & 1.68 & $7.4^{\mathrm{b}}$ & $8.6^{\mathrm{a}}$ & 0.35 & 68.8 & 65.5 & 2.58 & 142.8 & 141.8 & 1.18 & 4.8 & 4.7 & 0.20 & 105.8 & 105.7 & 1.07 \\
\hline 90 & $28.6^{\mathrm{b}}$ & $34.3^{\mathrm{a}}$ & 1.72 & $7.2^{\mathrm{b}}$ & $8.6^{\mathrm{a}}$ & 0.35 & 70.5 & 68.2 & 3.85 & $143.7^{\mathrm{a}}$ & $140.8^{\mathrm{b}}$ & 1.73 & 4.9 & 4.8 & 0.19 & 106.7 & 105.7 & 1.66 \\
\hline 120 & $28.8^{\mathrm{b}}$ & $34.5^{\mathrm{a}}$ & 2.10 & $7.3^{\mathrm{b}}$ & $8.7^{\mathrm{a}}$ & 0.33 & $72.8^{\mathrm{a}}$ & $65.7^{\mathrm{b}}$ & 3.98 & $146.8^{\mathrm{a}}$ & $142.2^{\mathrm{b}}$ & 1.67 & 4.6 & 4.8 & 0.20 & $108.7^{\mathrm{a}}$ & $105.3^{b}$ & 1.22 \\
\hline 150 & 27.0 & 29.6 & 1.76 & $7.0^{\mathrm{b}}$ & $7.9^{\mathrm{a}}$ & 0.40 & 71.7 & 68.3 & 3.63 & $144.8^{\mathrm{a}}$ & $140.7^{\mathrm{b}}$ & 1.29 & 4.5 & 4.7 & 0.20 & $105.8^{\mathrm{a}}$ & $102.0^{\mathrm{b}}$ & 1.08 \\
\hline
\end{tabular}

$\mathrm{NFC}=$ Normal feeding conditions; FBR = Feed bolus removal. Values are means of 6 large-type goats; SE = Pooled standard error.

${ }^{\mathrm{a}, \mathrm{b}}$ Means in the same row bearing different superscripts differ $(\mathrm{p}<0.05)$. 

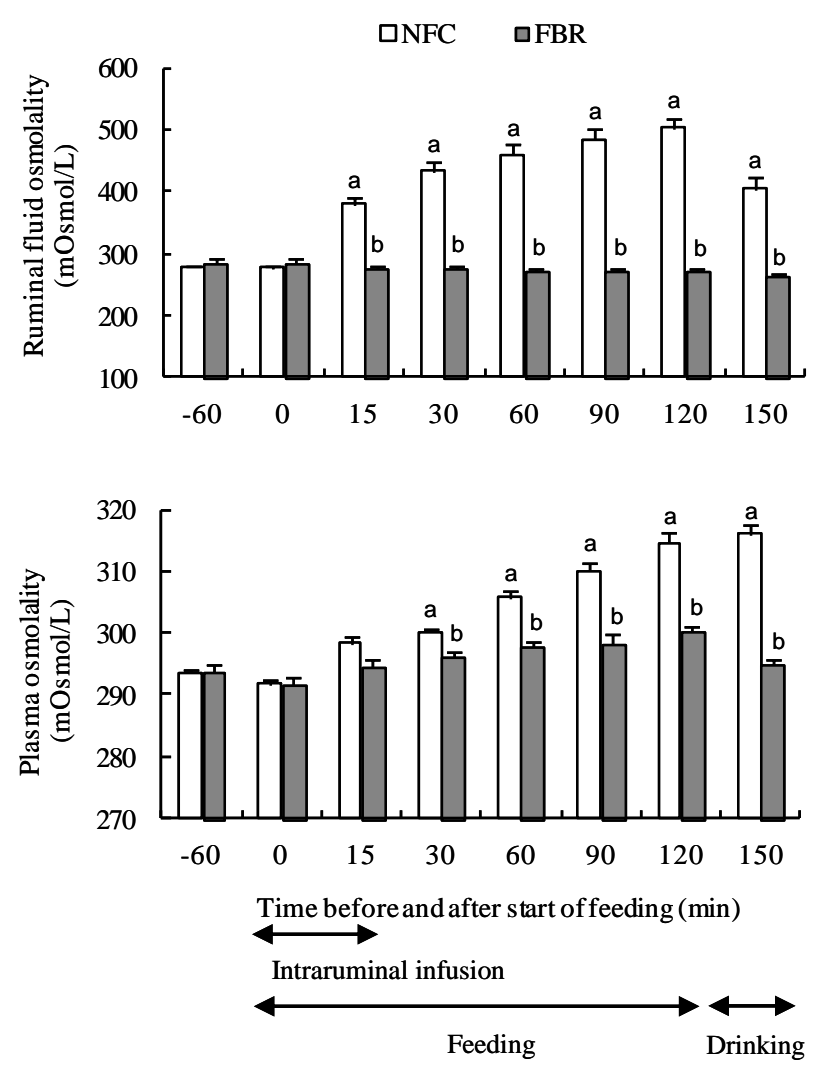

Figure 8. The effect of feed bolus removal (FBR) during dry forage feeding on osmolality of plasma and ruminal fluid. Values are means \pm SE of 6 large-type goats. ${ }^{a, b}$ Means with different superscript are significantly different $(\mathrm{p}<0.05)$ from normal feeding conditions (NFC).

Compared with the NFC control, plasma osmolality in the FBR treatment was significantly lower $(p<0.05)$ from 30 min after the start of feeding, even upon conclusion of the 30 min drinking period.

Ruminal fluid osmolality in the NFC control increased gradually as the feeding period elapsed and reached the highest level of $503.2 \pm 15.94 \mathrm{mOsmol} / \mathrm{L}$ upon conclusion of the $2 \mathrm{~h}$ feeding period. Meanwhile, ruminal fluid osmolality in the FBR treatment mostly remained unchanged during the $2 \mathrm{~h}$ feeding period. Compared with the NFC control, ruminal fluid osmolality in the FBR treatment was significantly lower $(\mathrm{p}<0.01)$ for the duration of the $2 \mathrm{~h}$ feeding period.

Ruminal fluid $\mathrm{pH}$ and concentrations of $\mathrm{Na}, \mathrm{K}$ and $\mathrm{Cl}$ : Table 4 presents the effect of FBR during dry forage feeding on ruminal fluid $\mathrm{pH}$ and concentrations of $\mathrm{Na}, \mathrm{K}$ and $\mathrm{Cl}$. Ruminal fluid $\mathrm{pH}$ in the NFC control decreased gradually and reached the lowest level of $6.08 \pm 0.07$ at 150 min interval. Meanwhile, ruminal fluid $\mathrm{pH}$ in the FBR treatment mostly remained unchanged for the duration of the $2 \mathrm{~h}$ feeding period. In comparison with the NFC control, ruminal fluid $\mathrm{pH}$ in the FBR treatment was significantly higher $(\mathrm{p}<0.01)$ during the $2 \mathrm{~h}$ feeding period.

There were no significant differences between the NFC control and the FBR treatment in terms of ruminal fluid concentrations of $\mathrm{Na}$ for the duration of the $2 \mathrm{~h}$ feeding period.

Ruminal fluid concentrations of $\mathrm{K}$ and $\mathrm{Cl}$ in the $\mathrm{NFC}$ control increased gradually as the feeding period had elapsed while they mostly remained unchanged in the FBR treatment during the $2 \mathrm{~h}$ feeding period. Compared with the $\mathrm{NFC}$ control, ruminal fluid concentrations of $\mathrm{K}$ and $\mathrm{Cl}$ in the FBR treatment were significantly lower $(p<0.05)$ over the $2 \mathrm{~h}$ feeding period.

\section{DISCUSSION}

\section{Esophageal fistulation and maintenance of esophageal fistulae in large-type goats}

In sheep, the esophageal fistula could not be maintained for long periods of time and therefore long-term experiments with esophageal-fistulated animals were not possible. The esophageal fistulation in large-type goats was performed using a two-step operation for esophageal fistulation in sheep described by Kato et al. (1983). We developed the technique in order to maintain the esophageal

Table 4. The effect of feed bolus removal during dry forage feeding on ruminal fluid $\mathrm{pH}$ and concentrations of $\mathrm{Na}, \mathrm{K}$, and $\mathrm{Cl}$

\begin{tabular}{|c|c|c|c|c|c|c|c|c|c|c|c|c|}
\hline \multirow{2}{*}{$\begin{array}{l}\text { Time before and } \\
\text { after start of } \\
\text { feeding ( } \mathrm{min})\end{array}$} & \multicolumn{3}{|c|}{ Ruminal fluid $\mathrm{pH}$} & \multicolumn{3}{|c|}{$\begin{array}{l}\text { Ruminal fluid } \mathrm{Na} \\
\qquad(\mathrm{mmol} / \mathrm{L})\end{array}$} & \multicolumn{3}{|c|}{$\begin{array}{l}\text { Ruminal fluid } \mathrm{K} \\
\text { (mmol/L) }\end{array}$} & \multicolumn{3}{|c|}{$\begin{array}{l}\text { Ruminal fluid } \mathrm{Cl} \\
\qquad(\mathrm{mmol} / \mathrm{L})\end{array}$} \\
\hline & NFC & FBR & SE & NFC & FBR & SE & NFC & FBR & SE & NFC & FBR & SE \\
\hline-60 & 6.93 & 6.94 & 0.13 & 140.5 & 130.7 & 14.38 & $70.2^{\mathrm{a}}$ & $56.3^{\mathrm{b}}$ & 8.90 & 33.5 & 43.4 & 4.14 \\
\hline 0 & 6.93 & 6.96 & 0.12 & 136.1 & 130.9 & 14.76 & 65.9 & 54.3 & 9.51 & 37.3 & 44.7 & 4.83 \\
\hline 15 & $6.42^{\mathrm{b}}$ & $7.20^{\mathrm{a}}$ & 0.12 & 130.8 & 131.7 & 11.56 & $89.2^{\mathrm{a}}$ & $50.3^{\mathrm{b}}$ & 9.53 & $57.0^{\mathrm{a}}$ & $40.6^{\mathrm{b}}$ & 4.54 \\
\hline 30 & $6.32^{\mathrm{b}}$ & $7.25^{\mathrm{a}}$ & 0.11 & 137.0 & 131.3 & 11.59 & $109.4^{\mathrm{a}}$ & $47.6^{\mathrm{b}}$ & 11.92 & $65.5^{\mathrm{a}}$ & $39.6^{\mathrm{b}}$ & 4.92 \\
\hline 60 & $6.29^{\mathrm{b}}$ & $7.25^{\mathrm{a}}$ & 0.12 & 137.2 & 129.6 & 11.63 & $117.0^{\mathrm{a}}$ & $48.7^{\mathrm{b}}$ & 13.48 & $70.7^{\mathrm{a}}$ & $39.6^{\mathrm{b}}$ & 5.09 \\
\hline 90 & $6.25^{\mathrm{b}}$ & $7.25^{\mathrm{a}}$ & 0.11 & 139.1 & 132.4 & 12.66 & $125.3^{\mathrm{a}}$ & $41.7^{\mathrm{b}}$ & 13.94 & $74.0^{\mathrm{a}}$ & $40.6^{\mathrm{b}}$ & 5.43 \\
\hline 120 & $6.15^{\mathrm{b}}$ & $7.25^{\mathrm{a}}$ & 0.11 & 135.2 & 129.8 & 10.84 & $124.2^{\mathrm{a}}$ & $43.5^{\mathrm{b}}$ & 13.37 & $73.1^{\mathrm{a}}$ & $40.6^{\mathrm{b}}$ & 4.60 \\
\hline 150 & $6.08^{b}$ & $7.26^{\mathrm{a}}$ & 0.12 & 114.2 & 123.9 & 15.75 & $107.1^{\mathrm{a}}$ & $40.3^{\mathrm{b}}$ & 11.27 & $59.8^{\mathrm{a}}$ & $39.6^{\mathrm{b}}$ & 5.53 \\
\hline
\end{tabular}

$\mathrm{NFC}=$ Normal feeding conditions; FBR $=$ Feed bolus removal. Values are means of 6 large-type goats; SE $=$ Pooled standard error.

${ }^{\mathrm{a}, \mathrm{b}}$ Means in the same row bearing different superscripts differ $(\mathrm{p}<0.05)$. 
fistula over a long period of time and to remove feed boluses smoothly after swallowing. The aim of the first step of the operation is to pull out and fix the esophagus under skin. If the first step operation fails, such as a stricture or twisting of the esophagus or the suture threads between the esophagus and skin are in the wrong direction, animals cannot swallow boluses and subsequently vomit them back up. In this case, it is necessary to repeat the first step again. Thus the step of esophagus-skin adhesion is a decisive factor for success or failure in the esophageal fistulation. In order to obtain good results from surgery, the second step should be done at least 30 days after the first step operation. This is the necessary duration for connective tissues to fully develop to keep the esophagus well under the skin and for animals to adapt to the new position of the esophagus during deglutition and rumination.

In order to maintain the esophageal-fistulated animals in good health, it is necessary to ensure that water, saliva and ruminal fluid do not leak from the esophageal fistulae during drinking, deglutition and rumination. Thus the esophageal fistula plugs play an important role in the maintenance of esophageal fistulae and good health in the esophageal-fistulated animals. If the esophageal fistula plugs do not completely close the esophageal fistulae, the leakage of water, saliva and ruminal fluid while drinking, deglutition and rumination may occur. If this continues for several days, the animal's health will be affected due to loss of saliva and ruminal fluid.

However, during the maintenance of esophageal fistulae for long-term experiments (four years), we had a little trouble with the esophageal fistulae such as impaction of the esophagus, injured esophageal lumen, leakage of ruminal fluid during rumination or water leakage during drinking due to the expanded esophageal fistulae. In addition, the esophageal fistula plugs were sometimes removed from esophageal fistulae. Impaction of the esophagus occasionally occurred. Symptoms of impaction were excessive salivation from the mouth or around the esophageal fistula. Most impaction can be solved by immediately removing the esophageal fistula plug, then gently removing all esophageal boluses from the fistula site. Subsequently, the esophageal fistula plug was washed and sterilized using tincture of iodine, and fitted again into the esophageal fistula. The esophageal lumen was injured by the rubbing of the esophageal lumen with the edges of the inner esophageal polypropylene plate during the movement of the esophagus. In order to solve this problem, we used a small silicone tube to cover the entire edges of the inner esophageal polypropylene plate and then coated it with a thin layer of silicone. As a result, the injured esophageal lumen did not occur again. In the case of expanded esophageal fistulae, which causes leakage of ruminal fluid during rumination or of water while drinking, we increased the sizes of the inner and outer sponges to fit and cover each expanded esophageal fistula. It is thought that for effective prevention of leakage of ruminal fluid and water from the expanded esophageal fistulae, the adjustment of the sponge sizes and replacement the sponges when damaged should be carried out in the course of maintenance of the esophageal fistulae. Nevertheless, in the case of expanded esophageal fistulae causing more leakage of water while drinking or of ruminal fluid during rumination, additional adjustments of the sponge sizes, a switch to a larger inner esophageal polypropylene plate was required. This effectively prevented further leakage of water during drinking and of ruminal fluid during rumination.

The sizes and shape of the esophageal cannula for collecting the boluses were designed and fabricated as shown in Figure 2A. Each esophageal cannula was fabricated to fit the esophageal fistula of each animal. If the esophageal cannula is not fitted into the esophageal fistula, a part of swallowed boluses will surely enter to the rumen. Thus using the esophageal cannula for collecting the boluses plays an important role in keeping the rumen contents unchanged during sham feeding conditions. The goats were not stressed when the esophageal cannulae were inserted into the esophageal fistulae, the alfalfa hay cubes used as feed were roughly crushed with any large remaining chunks removed, and the animals consumed significantly more feed than as observed under normal feeding conditions. An animal's stress level is indicated by plasma glucose concentrations and these values recorded in the animals under sham feeing conditions were within the normal range (Table 3).

\section{A stimulating factor of water intake during and after dry forage feeding}

The results of this study clarified that water intake during and after dry forage feeding in large-type goats fed dry forage for $2 \mathrm{~h}$ twice daily is not caused by decreased circulating plasma volume due to copious saliva secretion during dry forage feeding, but by increased plasma osmolality due to the ruminal absorption of salts from the consumed feed.

Ruminants that were fed on dry forage secrete copious amounts of saliva during the initial stages of feeding (Thang et al., 2010). Saliva is made from components in the blood and thus during the initial stages of feeding, large amounts of $\mathrm{NaHCO}_{3}$ and water are lost from the blood as saliva secretion increases. This causes a decrease in blood $\mathrm{pH}$ and a reduction in circulating plasma volume (Sasaki et al., 1974; 1975). Blair-West and Brook (1969) reported that a decrease in circulating plasma volume was reflected in an increase in hematocrit and plasma total protein concentrations. In the present study, under both normal feeding conditions and sham feeding conditions hematocrit 
and plasma total protein concentrations increased with dry forage feeding (Tables 1 and 3 ). This resulted in the secretion of the antidiuretic hormone (ADH) and a decrease in urine volume (Sasaki et al., 1975; McKinley et al., 1994). During the initial stages of dry forage feeding, it is thought that an increase in plasma renin concentration indicates activation of the renin-angiotensin system (Blair-West and Brook, 1969). Sunagawa et al. (2005) reported that when large-type goats fed dry forage for $2 \mathrm{~h}$ twice daily were intravenously infused with artificial saliva from two hours prior to feeding until one hour after feeding had commenced the suppression of saliva secretion and feed intake in the first hour of feeding was markedly reduced. This was caused by the decrease in circulating plasma volume brought about by the copious secretion of saliva during the initial stages of feeding. However, in the first hour of the $2 \mathrm{~h}$ feeding period in the WA treatment of experiment 1 , there was very little drinking behavior observed and the most of the water consumption occurred in the second hour of the $2 \mathrm{~h}$ feeding period (Figure 4 ). In large-type goats fed dry forage for $2 \mathrm{~h}$ twice daily, under sham feeding conditions whereby feed boluses were removed via an esophageal fistula before they could enter the rumen, feed intake was greater than under normal feeding conditions but cumulative water intake under sham feeding conditions was significantly less upon conclusion of the 30 min drinking period (Figure 7; Thang et al., 2010). It is therefore thought that water intake during and after dry forage feeding is controlled by factors produced when feed boluses enter the rumen.

In the second hour of the $2 \mathrm{~h}$ feeding period, ruminal osmolality increased and at the same time the ruminal wall was distended due to feed boluses entering the rumen (Thang et al., 2010). Furthermore, the ruminal absorption of salt contents from the consumed feed caused an increase in plasma osmolality which induced more frequent drinking behavior (Figures 4 and 5). In the WA treatment of experiment 1 , small amounts of water were consumed during the first hour of feeding while the marked increase in water intake was observed during the second hour of feeding (Figure 4). The amount of water consumed in the second hour of the $2 \mathrm{~h}$ feeding period accounted for $82.8 \%$ of the total water intake. In experiment 2 , water intake in the FBR treatment was significantly less $(p<0.01)$ than compared to the NFC control (Figure 7). The results of the present study indicate that in large-type goats fed dry forage for $2 \mathrm{~h}$ twice daily, water intake during and after dry forage feeding is controlled by increase in plasma osmolality caused by the ruminal absorption of salt contents from the consumed feed.

Thirst is a subjective perception that provides the urge for humans and animals to drink fluids (McKinley and Johnson, 2004). The desire to drink is completely satisfied only when plasma osmolality or blood volume returns to normal. The sensation of thirst is produced in the brain as a result of the integration of neuronal and humoral information (Fitzsimons, 1979). Neuronal information is transported via the autonomic nerve (especially the vagus) from chemoreceptors in the internal visceral organs. A broad range of internal humoral information is transported via the blood and cerebrospinal fluid. Increased extracellular fluid osmolality, decreases in extracellular fluid volume, the production of angiotensin II, and dryness of the mouth stimulate the sensation of thirst in the brain (Guyton and Hall, 1996). In experiment 2, water intake in the FBR treatment following the conclusion of the $2 \mathrm{~h}$ feeding period was significantly less $(p<0.01)$ than that in the NFC control (Figure 7). The decrease in plasma volume in the FBR treatment, which was estimated by dry forage feeding induced increases in hematocrit and plasma total protein concentrations, was larger $(\mathrm{p}<0.05)$ than compared to the NFC control in the second hour of the $2 \mathrm{~h}$ feeding period. However, plasma osmolality in the FBR treatment was significantly lower $(p<0.05)$ than that in the NFC control from $30 \mathrm{~min}$ after the start of feeding (Figure 8; Table 3). While the level of plasma osmolality in the FBR treatment in the second hour of the $2 \mathrm{~h}$ feeding period was slightly higher than the level of that prior to feeding, the level of plasma osmolality in the NFC control in the second hour of the $2 \mathrm{~h}$ feeding period was markedly greater than the level of that prior to feeding. These results indicate that water intake in the second hour of the $2 \mathrm{~h}$ feeding period in large-type goats fed on dry forage for $2 \mathrm{~h}$ twice daily is not caused by decreases in circulating plasma volume due to copious saliva secretion during dry forage feeding, but rather by increases in plasma osmolality brought about by ruminal absorption of salts from the consumed feed.

Ciura and Bourque (2006) reported that neural cells sensitive to increases in osmolality of extracellular fluid exist in the organum vasculosum lamina terminalis (OVLT) in the anteroventral wall of the third ventricule in mice. Oldfield et al. (1994) reported that the populations of neurons in the organum vasculosum lamina terminalis, the subfornical organ (SFO), and median preoptic nucleus (MnPO) in the lamina terminalis are activated by intravenous infusion of either hypertonic saline or angiotensin II (ANG II). Sunagawa et al. (2001) reported that in sheep fed on dry alfalfa chaff once a day, an intracerebroventricular infusion of angiotensin II induced thirst sensations and reduced feed intake. Mathai et al. (1977) reported that in sheep fed oaten-lucerne chaff intracerebroventricular infusion of the $\mathrm{AT}_{1}$ type angiotensin II receptor blocker losartan reduced postprandial drinking. These reports support the present results that indicate increased water intake in the second hour of the $2 \mathrm{~h}$ feeding period in large-type goats fed on dry forage for $2 \mathrm{~h}$ twice 
daily is the result of increases in plasma osmolality, caused by the ruminal absorption of salts from the consumed feed, that in turn bypassed the blood-brain barrier and activated the osmosensitive neurons in the circumventricular organs.

\section{ACKNOWLEDGEMENTS}

We thank Miss Yui Naito, Miss Tomoko Sasaki, Mr. Yutaro Tominaga and Miss Yuki Nishida for their helpful assistance in experiments and recording the data. We also thank Mr. Glenn McIlvride for his English proof-reading on this manuscript.

\section{REFERENCES}

AOAC. 1990. Official methods of analysis. 15th Ed. Association of Official Analytical Chemists, Arlington, Virginia.

Blair-West, J. R. and A. H. Brook. 1969. Circulatory changes and renin secretion in sheep in response to feeding. J. Physiol. 204:15-30.

Ciura, S. and C. W. Bourque. 2006. Transient receptor potential vanilloid 1 is required for intrinsic osmoreception in organum vasculosum lamina terminalis neurons and for normal thirst responses to systemic hyperosmolality. J. Neurosci. 26:90699075.

Fitzsimons, J. T. 1979. The physiology of thirst and sodium appetite. Cambridge University Press, Cambridge, UK. pp. 59.

Guyton, A. C. and J. E. Hall. 1996. Central nervous system centers for thirst. In: Textbook of Medical Physiology. W. B. Saunders Company, Philadelphia, Pennsylvania. pp. 361.

Kato, S., S. Watanabe, Y. Otomo, Y. Sasaki and T. Tsuda. 1983. Two step operation for esophageal fistulation in sheep. Tohoku Journal of Agricultural Research, Japan. 33:125-130.

Mathai, M., M. D. Evered and M. J. McKinley. 1997. Intracerebroventricular losartan inhibits postprandial drinking in sheep. Am. J. Physiol. 272:R1055-R1059.

McKinley, M. J., R. B. Harvey and L. Vivas. 1994. Reducing brain sodium concentration prevents post-prandial and dehydrationinduced natriuresis in sheep. Acta Physiol. Scand. 151:467-476.
McKinley, M. J. and A. K. Johnson. 2004. The physiological regulation of thirst and fluid intake. News Physiol. Sci. 19:1-6.

Oldfield, B. J., E. Badoer, D. K. Hards and M. J. McKinley. 1994. Fos production in retrogradely labelled neurons of the lamina terminalis following intravenous infusion of either hypertonic saline or angiotensin II. Neuroscience 60:255-262.

Paquay, R., R. De Baere and A. Lousse. 1970. Statistical research on the fate of water in the adult cows. I. Dairy cows. J. Agric. Sci. 74:423-432.

Prasetiyono, B. W. H. E., K. Sunagawa, A. Shinjo and S. Shiroma. 2000. Physiological relationship between thirst level and feed intake in goats fed on alfalfa hay cubes. Asian-Aust. J. Anim. Sci. 13:1536-1541.

SAS. 1990. SAS/STAT user's guide: Volume 2, Version 6. 4th Ed. SAS Institute Inc., SAS Campus Drive, Cary, NC 27513.

Sasaki, Y., S. Watanabe, Y. Sato, S. Kato and T. Tsuda. 1974. Changes in acid-base status of sheep during eating. Jpn. J. Zootech. Sci. 45:8-13.

Sasaki, Y., S. Watanabe, Y. Sato and S. Kato. 1975. Effect of intravenous infusion of artificial saliva on changes in acid-base status of sheep during eating. Jpn. J. Zootech. Sci. 46:449-453.

Sunagawa, K., T. Hashimoto, M. Izuno, N. Hashizume, M. Okano, I. Nagamine, T. Hirata and A. Shinjo. 2008. An intravenous replenishment of salivary components decreases water intake and increases feed intake in freely drinking large-type goats fed dry forage. Can. J. Anim. Sci. 88:237-245.

Sunagawa, K., T. Ooshiro, N. Nakamura, I. Nagamine, S. Shiroma and A. Shinjo. 2005. Controlling factors of feed intake and salivary secretion in goats fed on dry forage. Asian-Aust. J. Anim. Sci. 18:1414-1420.

Sunagawa, K., R. S. Weisinger, M. J. McKinley, B. S. Purcell, C. Thomson and P. L. Burns. 2001. The role of angiotensin II in the central regulation of feed intake in sheep. Can. J. Anim. Sci. $81: 215-221$

Thang, T. V., K. Sunagawa, I. Nagamine and S. Kato. 2010. Deprivation of esophageal boluses and dry forage intake in large-type goats. Asian-Aust. J. Anim. Sci. 23:1174-1183.

Van Soest, P. J., J. B. Robertson and B. A. Lewis. 1991. Methods for dietary fiber, neutral detergent fiber, and nonstarch polysaccharides in relation to animal nutrition. J. Dairy Sci. 74:3583-3597. 